\title{
Isolation and Antimicrobial Activity of Rutin and Its Derivatives from Ruta chalepensis (Rutaceae) Growing in Iraq
}

\author{
Shaymaa Al-Majmaie ${ }^{\oplus 1}$, Lutfun Nahar ${ }^{\oplus 1}$, George P. Sharples ${ }^{\oplus 1}$, \\ Khazal Wadi $^{\oplus 2}$ and Satyajit D. Sarker ${ }^{\oplus 1}$ \\ ${ }^{1}$ Medicinal Chemistry and Natural Products Research Group, School of Pharmacy and Biomolecular \\ Sciences, Faculty of Science, Liverpool John Moores University, James Parsons Building, \\ Byrom Street, Liverpool L3 3AF, United Kingdom \\ ${ }^{2}$ Department of Biology, College of Science, University of Diyala, Baquba, Iraq \\ (Received March 09, 2018; Revised May 8, 2018; Accepted May 16, 2018)
}

\begin{abstract}
Rutin (1), rutin 3'-methyl ether (2), and a new flavonol glycoside, 6-hydroxy-rutin 3',7-dimethyl ether (3), were isolated from the methanol extract of the fruits of Ruta chalepensis, collected from Diyala, Iraq. Their structures were elucidated by spectroscopic analyses, including 1D-, 2D-NMR and HRESIMS. Antimicrobial activity of compounds 1-3 was tested against four Gram +ve and Gram -ve bacterial strains, and the only fungal strain, Candida albicans, using the 96-well based resazurin microtitre assay.
\end{abstract}

Keywords: Ruta chalepensis; Rutaceae; resazurin assay; antimicrobial activity; rutin; 6-hydroxy-rutin 3',7dimethyl ether. (C) 2018 ACG Publications. All rights reserved.

\section{Introduction}

Ruta chalepensis L. (family: Rutaceae), commonly known as "fringed rue", is a perennial herb (ca. $80 \mathrm{~cm}$ tall), native to Eurasia and North Africa and introduced elsewhere [1-4]. Different parts of this plant have been used for centuries in traditional medicine to treat convulsions, dropsy, fever, mental disorders, menstrual problems, neuralgia, rheumatism, and other bleeding and nervous disorders [2, 4-6]. Whilst previous phytochemical studies on this plant revealed the presence of several alkaloids, anthraquinones, cardiac glycosides, coumarins, flavonoids, saponins, tannins and terpenoids [3, 4, 7-10], pharmacological evaluations established its analgesic, anthelmintic, antiacetylcholinesterase, anticancer, anti-inflammatory, antimicrobial, antioxidant and antiparasitic properties $[1,5-8,11-15]$. We now report on the isolation, characterization and antimicrobial activity of three flavonol glycosides (1-3) (Figure 1) including a new one, 6-hydroxy-rutin 3',7-dimethyl ether (3) from the fruits of $R$. chalepensis, collected in Iraq.

\section{Materials and Methods}

\subsection{General}

Chromatographic solvents were purchased from Fisher Scientific, UK, and used without further purification. The NMR spectroscopic analyses were performed on a Bruker AMX600 NMR

\footnotetext{
* Corresponding author: E-mail: S.Sarker@ljmu.ac.uk
} 
spectrometer $\left(600 \mathrm{MHz}\right.$ for ${ }^{1} \mathrm{H}$, and $150 \mathrm{MHz}$ for ${ }^{13} \mathrm{C}$ ). MS analyses were performed on a Xevo G2-S ASAP or LTQ Orbitrap XL 1 spectrometers. UV spectra were recorded on Analytik Jena Specord 210 spectrophotometer. The SPE fractions were analysed on a Dionex Ultimate 3000 UHPLC coupled with a photodiode array (PDA) detector, using a Phenomenex Gemini-NX 5 U C $_{18}$ column $(150 \times 4.6$ $\mathrm{mm}, 5 \mu \mathrm{m}$, Phenomenex, USA) and gradient solvent systems comprising $\mathrm{MeOH}$ (solvent $\mathrm{B}$ ) and water (solvent A) (both contained $0.1 \%$ TFA, flow rate: $1 \mathrm{~mL} / \mathrm{min}$ ) were employed to optimize separation of compounds for preparative HPLC. An Agilent 1260 Infinity series preparative HPLC coupled with a PDA detector was used to isolate compounds on an ACE preparative column $(150 \times 21.2 \mathrm{~mm}, 5 \mu \mathrm{m}$, Hichrom Ltd, UK; MeOH-water linear gradient, flow rate: $10 \mathrm{~mL} / \mathrm{min}$ ). The column temperature was set at $25{ }^{\circ} \mathrm{C}$. The chromatogram was monitored at variable UV-vis wavelengths $(215,254,280$ and $320 \mathrm{~nm})$.<smiles>[R20]Oc1cc(-c2oc3cc([R20])c([R])c(O)c3c(=O)c2O[Ga])ccc1O</smiles>

\begin{tabular}{llll}
\hline Compounds & $\mathrm{R}$ & $\mathrm{R}^{\prime}$ & $\mathrm{R} "$ \\
\hline Rutin (1) & $\mathrm{H}$ & $\mathrm{H}$ & $\mathrm{H}$ \\
Rutin 3'-methyl ether (2) & $\mathrm{Me}$ & $\mathrm{H}$ & $\mathrm{H}$ \\
6-Hydroxy-rutin 3'-7-dimethyl ether (3) & $\mathrm{Me}$ & $\mathrm{Me}$ & $\mathrm{OH}$ \\
\hline
\end{tabular}

Figure 1. Structures of flavonol glycosides 1-3

\subsection{Plant Materials}

The fruits of $R$. chalepensis L. were collected from Diyala, Central Iraq (N 33.79684 E 44.623337) in September 2015, air-dried at room temperature, and ground using a coffee grinder. A voucher specimen (33396) for this collection has been retained at the National Herbarium of Iraq.

\subsection{Extraction and Isolation}

Ground air-dried fruits (103 g) were Soxhlet-extracted, successively, with $n$-hexane, dichloromethane (DCM) and methanol $(\mathrm{MeOH})(0.9 \mathrm{~L}, 10$ cycles each). All extracts were evaporated to dryness using a rotary evaporator at $45^{\circ} \mathrm{C}$ to obtain $4.6 \mathrm{~g}, 4.2 \mathrm{~g}$ and $6.0 \mathrm{~g}$ of $n$-hexane, DCM and $\mathrm{MeOH}$ extracts, respectively. A portion ( $2 \mathrm{~g}$ ) of the active $\mathrm{MeOH}$ extract was subjected to solid-phase extraction (SPE) on a Strata $\left(20 \mathrm{~g}\right.$, Phenomenex) $\mathrm{C}_{18}$ reversed-phase cartridge eluted with water$\mathrm{MeOH}$ mixture of decreasing polarity, water:MeOH 80:20, 50:50, 20:80 and 0:100 (250 mL each), to obtain four SPE fractions I-IV, respectively. All SPE fractions were dried using a rotary evaporator followed by freeze-drying and stored in sealed vials in a fridge for further work. Reversed-phase preparative HPLC purification of the SPE fraction II (linear gradient: solvent B in A, 30-100\% in 30 $\mathrm{min})$ afforded compounds $1\left(3.5 \mathrm{mg}, t_{\mathrm{R}}=15.9 \mathrm{~min}\right), \mathbf{2}\left(2.1 \mathrm{mg}, t_{\mathrm{R}}=17.1 \mathrm{~min}\right)$ and $\mathbf{3}\left(3.2 \mathrm{mg}, t_{\mathrm{R}}=18.0\right.$ min), respectively.

Rutin (1): Yellow amorphous solid; UV $\lambda_{\max }(\mathrm{MeOH}) \mathrm{nm}$ : 257, 267 (sh), $300(\mathrm{sh})$ and $359 \mathrm{~nm} ;{ }^{1} \mathrm{H}$ NMR ( $\left.\mathrm{CD}_{3} \mathrm{OD}, 600 \mathrm{MHz}\right)$, see Table $1 ;{ }^{13} \mathrm{C}$ NMR $\left(\mathrm{CD}_{3} \mathrm{OD}, 150 \mathrm{MHz}\right)$, see Table 2; HRESIMS (negative ion mode) $m / z$ 609.1456 [M-H]', (calcd. for $\mathrm{C}_{27} \mathrm{H}_{29} \mathrm{O}_{16}, m / z$ 609.1456) [16].

Rutin 3'-methyl ether (2): Brown amorphous solid; UV $\lambda_{\max }(\mathrm{MeOH}) \mathrm{nm}: 254,264$ (sh), 304 (sh) and $354 \mathrm{~nm} ;{ }^{1} \mathrm{H}$ NMR $\left(\mathrm{CD}_{3} \mathrm{OD}, 600 \mathrm{MHz}\right)$, see Table $1 ;{ }^{13} \mathrm{C}$ NMR $\left(\mathrm{CD}_{3} \mathrm{OD}, 150 \mathrm{MHz}\right)$, see Table 2; HRESIMS (positive ion mode) $m / z$ 625.1761[M+H] ${ }^{+}$(calcd. for $\mathrm{C}_{28} \mathrm{H}_{33} \mathrm{O}_{16}, m / z$ 625.1769) [16-18]. 
6-Hydroxy-rutin 3', 7-dimethyl ether (3): Brown amorphous solid; UV $\lambda_{\max }(\mathrm{MeOH}) \mathrm{nm}: 252,260$ (sh), 306 (sh) and $360 \mathrm{~nm} ;{ }^{1} \mathrm{H}$ NMR $\left(\mathrm{CD}_{3} \mathrm{OD}, 600 \mathrm{MHz}\right)$, see Table $1 ;{ }^{13} \mathrm{C}$ NMR $\left(\mathrm{CD}_{3} \mathrm{OD}, 150 \mathrm{MHz}\right)$, see Table 2; HRESIMS (positive ion mode) $m / z 655.1870[\mathrm{M}+\mathrm{H}]^{+}$(calcd. for $\mathrm{C}_{29} \mathrm{H}_{35} \mathrm{O}_{17}, m / z$ 655.1874).

\subsection{Antimicrobial Assay (Resazurin Assay)}

All three compounds (1-3) were screened for their potential antimicrobial activity against four bacterial strains, e.g., Gram +ve: Micrococcus luteus (NCTC 7508) and Staphylococcus aureus (NCTC 12981) and Gram -ve: Escherichia coli (NCTC12241) and Pseudomonas aeruginosa (NCTC 12903), and a fungal strain, Candida albicans (ATCC 90028) using the resazurin 96-well microtitre plate-based in vitro antimicrobial assay [19]. All bacterial strains were cultured on nutrient agar (Oxoid) and incubated for $24 \mathrm{~h}$ at $37^{\circ} \mathrm{C}$ to determinate the MIC. Ciprofloxacin was used as a positive control for bacterial strains, and nystatin for C. albicans. Resazurin solution, prepared by dissolving 1 $\mathrm{mg}$ of resazurin in $5 \mathrm{~mL}$ of sterile distilled water, was used in this assay as an indicator of cell growth, and the method was as described by Sarker et al. [19]. This experiment was performed under aseptic conditions using a sterile 96 well plate. Compound solution $(100 \mu \mathrm{L})$ was added into the first row of the plate and $50 \mu \mathrm{L}$ of normal saline was added to all other wells. Serial dilutions were achieved using a multichannel pipette. To each well, $30 \mu \mathrm{L}$ of nutrient broth and $10 \mu \mathrm{L}$ of resazurin indicator solution were added. Finally, $10 \mu \mathrm{L}$ of bacterial suspension $(5 \times 105 \mathrm{cfu} / \mathrm{mL})$ was added to each well. To prevent bacterial dehydration, each plate was wrapped loosely with cling film. Every plate contained a positive control. Any colour changes (or no changes in positive control), blue to pink, were noted. The lowest concentration was taken in the colour change that occurred as an MIC (minimum inhibitory concentration) value. The mean of three values was calculated.

\subsubsection{Determination of Bacteriostatic or Bactericidal Property}

To determine whether the compounds were bacteriostatic or bactericidal, under aseptic condition, $100 \mu \mathrm{L}$ of culture from the rows of MIC in the microtitre plates was transferred to an empty petri dish, $20 \mathrm{~mL}$ of nutrient agar was poured on to the dish, and incubated at $37^{\circ} \mathrm{C}$ for $24 \mathrm{~h}$. Any microbial regrowth indicated bacteriostatic, and no growth indicated bactericidal activity of the test sample.

\section{Results and Discussion}

\subsection{Extraction, Isolation and Structure Elucidation of Rutin Derivatives (1-3)}

Soxhlet extraction of the dried and ground fruits of Ruta chalepensis afforded 4.6, 4.2 and 6.0 $\mathrm{g}$ of $n$-hexane, DCM and $\mathrm{MeOH}$ extracts, respectively. SPE of the MeOH extract, the most active extract of the three, produced $0.45,0.49,0.50$ and $0.40 \mathrm{~g}$ of SPE fractions, eluted with $20,50,80$ and $100 \% \mathrm{MeOH}$ in water, indicating an excellent recovery of the sample from the SPE cartridge. Antimicrobial assay-guided and preparative HPLC-assisted purification of the most active SPE fraction II afforded compounds 1-3. The UV-Vis spectral analyses of the compounds 1-3 indicated that they were flavonoid glycosides, possibly with rutin-type skeleton [18]. The HRESIMS analyses of these compounds (1-3) provided their molecular formula, $\mathrm{C}_{27} \mathrm{H}_{30} \mathrm{O}_{16}, \mathrm{C}_{28} \mathrm{H}_{32} \mathrm{O}_{16}$ and $\mathrm{C}_{29} \mathrm{H}_{34} \mathrm{O}_{17}$, respectively, suggesting compound $\mathbf{1}$ could be rutin. It also added further evidence to the assumption made from the UV-Vis data that compounds 1-3 could be rutin derivatives. In fact, according to the HRESIMS data, compound 2 had just 14 amu unit more than that of rutin (1) suggesting this compound could be a methyl ether of rutin (1). Similarly, the molecular mass of compound $\mathbf{3}$ was 44 amu unit higher than that of rutin (1), indicating this compound could be a dimethyl ether analogue of 1 with an additional hydroxyl group. The ${ }^{1} \mathrm{H}$ and ${ }^{13} \mathrm{C}$ NMR data (Tables 1 and 2) of compounds 1 and 2 were in good agreement with respective published data for rutin (1) and rutin 3'-methyl ether (2) [1618]. The attachment of the rutinosyl moiety at C-3 in compounds $\mathbf{1}$ and $\mathbf{2}$, and the methyl ether formation at C-3' in compound $\mathbf{2}$ were confirmed from extensive HSQC and HMBC experiments. 
The ${ }^{1} \mathrm{H}$ NMR spectrum (Table 1) of compound $\mathbf{3}$ was quite similar to that of compound $\mathbf{2}$, with the exception that there was a downfield $6 \mathrm{H}$ singlet at 83.97 , and instead of the usual shielded aromatic meta-coupled proton signals for H-6 and H-8 in flavonol skeleton, there was only a $1 \mathrm{H}$ singlet at $\delta 6.53$ suggesting that one of those protons was substituted by an extra functional group, most likely a hydroxyl group based on the HRESIMS data. The ${ }^{13} \mathrm{C}$ NMR spectrum of $\mathbf{3}$ (Table 2) showed the presence of an additional oxygenated aromatic quaternary signal at $\delta 145.3$, which could be assigned to C-6 or C-8. Whilst a COSY experiment of compound 3 established all major ${ }^{1} \mathrm{H}-{ }^{1} \mathrm{H}$ scalar couplings, ${ }^{1} \mathrm{H}-{ }^{13} \mathrm{C}$ direct $\left({ }^{1} \mathrm{~J}\right)$ couplings were obtained from an HSQC experiment confirming the assignment of all protonated ${ }^{13} \mathrm{C}$ signals to their respective ${ }^{1} \mathrm{H}$ signals. An $\mathrm{HMBC}$ experiment displayed all major ${ }^{1} \mathrm{H}-{ }^{13} \mathrm{C}$ long-range $\left({ }^{2} J\right.$ and $\left.{ }^{3} J\right)$ correlations (Figure 2). The rhamnose anomeric proton (H-1"') showed a ${ }^{3} J$ correlation to C-6"' of the glucose unit, and the glucose anomeric proton $(\mathrm{H}-1 ")$ displayed a ${ }^{3} J$ correlation to $\mathrm{C}-3$ of the flavonol aglycones, confirming the formation of the disaccharide, rutinose, and its connection to C-3 (as in compounds $\mathbf{1}$ and 2). Similarly, ${ }^{3} J$ correlations from the methoxyl signal at $83.97(6 \mathrm{H})$ (Table 1) to C-7 and C-3' (Table 2) established methyl ether formation at C-7 and C-3' (Figure 2). The ${ }^{13} \mathrm{C}$ NMR (Table 2) signal at 896.4 confirmed that the hydroxylation was indeed on C-6 in compound 3 , and this fact was further corroborated from the ${ }^{1} \mathrm{H}-$ ${ }^{13} \mathrm{C}$ HMBC long-range correlations from $\mathrm{H}-8$ signal to C-6 and C-10 (Figure 2). Thus, the compound 3 was identified as 6-hydroxy-rutin 3',7-dimethyl ether (3), which to the best of our knowledge, is a new natural product. This is also the first report on any assay-guided phytochemical analysis of the fruits of Iraqi $R$. chalepensis.

Table 1. ${ }^{1} \mathrm{H}$ NMR data for compounds $\mathbf{1 - 3}$ (at $600 \mathrm{MHz}$ in $\mathrm{CD}_{3} \mathrm{OD}, \delta$ in ppm, $J$ in $\mathrm{Hz}$ )

\begin{tabular}{|c|c|c|c|}
\hline Position (H) & 1 & 2 & 3 \\
\hline \multicolumn{4}{|l|}{ Aglycone } \\
\hline 6 & $6.23(1 \mathrm{H}, d, J=2.1)$ & $6.23(1 \mathrm{H}, d, J=2.0)$ & - \\
\hline 8 & $6.42(1 \mathrm{H}, d, J=2.1)$ & $6.44(1 \mathrm{H}, d, J=2.0)$ & $6.53(1 \mathrm{H}, s)$ \\
\hline $2^{\prime}$ & $7.69(1 \mathrm{H}, d, J=2.0)$ & $7.96(1 \mathrm{H}, d, J=2.0)$ & $8.00(1 \mathrm{H}, d, J=2.0)$ \\
\hline $5^{\prime}$ & $6.89(1 \mathrm{H}, d, J=8.4)$ & $6.94(1 \mathrm{H}, d, J=8.4)$ & $6.94(1 \mathrm{H}, d, J=8.4)$ \\
\hline $6^{\prime}$ & $7.65(1 \mathrm{H}, d d, J=2.0,8.4)$ & $7.65(1 \mathrm{H}, d d, J=2.0,8.4)$ & $7.80(1 \mathrm{H}, d d, J=2.0,8.4)$ \\
\hline 7-OMe & - & - & $3.97(3 \mathrm{H}, s)$ \\
\hline 3'-OMe & - & $3.97(3 \mathrm{H}, s)$ & $3.97(3 \mathrm{H}, s)$ \\
\hline \multicolumn{4}{|c|}{ Glucose moiety } \\
\hline 1" & $5.12(1 \mathrm{H}, d, J=7.7)$ & $5.25(1 \mathrm{H}, d, J=7.6)$ & $5.25(1 \mathrm{H}, d, J=7.4)$ \\
\hline $2^{\prime \prime}$ & $3.49 *$ & $3.49 *$ & $3.49 *$ \\
\hline $3 "$ & $3.31 *$ & $3.32 *$ & $3.31 *$ \\
\hline 4" & $3.29 *$ & $3.30 *$ & $3.29 *$ \\
\hline $5^{\prime \prime}$ & $3.43^{*}$ & $3.46^{*}$ & $3.43^{*}$ \\
\hline \multirow[t]{2}{*}{$6^{\prime \prime}$} & $3.41 *$ & $3.44 *$ & $3.44 *$ \\
\hline & $3.81(1 \mathrm{H}, m)$ & $3.84(1 \mathrm{H}, m)$ & $3.84(1 \mathrm{H}, m)$ \\
\hline \multicolumn{4}{|c|}{ Rhamnose moiety } \\
\hline 1"' & $4.54(1 \mathrm{H}, d, J=1.5)$ & $4.55(1 \mathrm{H}, d, J=1.5)$ & $4.54(1 \mathrm{H}, d, J=1.4)$ \\
\hline $2^{\prime \prime \prime}$ & $3.65^{*}$ & $3.63 *$ & $3.60 *$ \\
\hline 3"' & $3.55 *$ & $3.56^{*}$ & $3.54 *$ \\
\hline 4"' & $3.30 *$ & $3.28 *$ & $3.28 *$ \\
\hline $5 " '$ & $3.46^{*}$ & $3.43^{*}$ & $3.43 *$ \\
\hline 6"' & $1.14(3 \mathrm{H}, d, J=6.2)$ & $1.11(3 \mathrm{H}, d, J=6.2)$ & $1.11(3 \mathrm{H}, d, J=6.3)$ \\
\hline
\end{tabular}

*Overlapped peaks - confirmed from COSY. HSQC and HMBC experiments

\subsection{Antimicrobial Activity}

Potential antimicrobial properties of rutin (1) and its two derivatives (2 and 3) were assessed against two Gram +ve, two Gram - ve bacterial species, and a fungal strain (Table 3). All compounds (1-3) showed various degrees of activities against all tested organisms in the resazurin microtitre assay [19]. Among three compounds, compound $\mathbf{3}$ was the most potent one, and the order of antimicrobial 
potency among these compounds was $\mathbf{3}>\mathbf{2}>\mathbf{1}$, which indicated that the addition of methyl ether functionality on rutin (1) enhanced the potency; more the number of methoxyl groups, the better was the activity. In fact, the cell membrane is considered as a direct target of antibacterial action of flavonoids, suggesting that membrane interaction could be an important mechanism of antibacterial activity of flavonoids, and increased lipophilicity in flavonoids might lead to enhanced membrane interaction [20].

\begin{tabular}{clll}
\hline Position (C) & $\mathbf{1}$ & $\mathbf{2}$ & $\mathbf{3}$ \\
\hline Aglycone & & & \\
2 & 159.5 & 159.0 & 159.3 \\
3 & 135.7 & 135.6 & 135.3 \\
4 & 179.5 & 179.5 & 180.0 \\
5 & 163.2 & 163.2 & 153.2 \\
6 & 100.0 & 100.1 & 127.8 \\
7 & 166.2 & 166.2 & 155.5 \\
8 & 95.0 & 95.0 & 96.4 \\
9 & 158.5 & 158.7 & 145.3 \\
10 & 105.7 & 105.9 & 106.0 \\
1' & 123.2 & 123.2 & 123.3 \\
2' & 117.8 & 114.7 & 114.8 \\
3' & 146.0 & 148.5 & 148.5 \\
4' & 150.4 & 151.0 & 151.0 \\
5' & 116.2 & 116.3 & 116.2 \\
6' & 123.7 & 124.2 & 124.7 \\
7-OMe & - & - & 57.2 \\
3'-OMe & - & 56.9 & 56.9 \\
Glucose moiety & & & \\
1" & 104.8 & 104.5 & 104.5 \\
2" & 75.9 & 76.1 & 76.1 \\
3" & 77.4 & 72.4 & 72.4 \\
4" & 71.5 & 77.5 & 77.5 \\
5" & 78.3 & 78.3 & 78.3 \\
6" & 68.7 & 68.1 & 68.7 \\
Rhamnose moiety & & & \\
1"' & 102.5 & 102.7 & 102.7 \\
2"' & 72.2 & 72.2 & 72.2 \\
3"' & 72.4 & 71.8 & 71.8 \\
4'" & 74.1 & 74.0 & 74.0 \\
5"' & 69.8 & 69.9 & 69.9 \\
6"' & 18.0 & 18.0 & 18.0 \\
\hline
\end{tabular}

*at $150 \mathrm{MHz}$ in $\mathrm{CD}_{3} \mathrm{OD}, \delta$ in ppm

Table 3. Antimicrobial activity of compounds 1-3

\begin{tabular}{llllll}
\hline \multirow{2}{*}{ Test organisms } & \multicolumn{3}{c}{ Minimum inhibitory concentration (MIC) in $\mu \mathbf{M}$} \\
\cline { 2 - 6 } & \multicolumn{3}{c}{ Positive controls } & \multicolumn{3}{c}{ Compounds } \\
\cline { 2 - 6 } & Ciprofloxacin & Nystacin & $\mathbf{1}$ & $\mathbf{2}$ & $\mathbf{3}$ \\
\hline Escherichia coli (NCTC 12241) & 1.473 & N/A & 1638.9 & 1601.2 & 774.5 \\
Micrococcus luteus (NCTC 7508) & 2.947 & N/A & 409.7 & 200.1 & 193.6 \\
Pseudomonas aeruginosa (NCTC 12903) & $7.36 \times 10^{-1}$ & N/A & 1638.9 & 800.6 & 387.3 \\
Staphylococcus aureus (NCTC 12981) & 2.947 & N/A & 1638.9 & 1601.2 & 1459.1 \\
Candida albicans (ATCC 90028) & N/A & 1.054 & 204.9 & 100.1 & 96.8 \\
\hline
\end{tabular}

All three compounds were particularly active against the fungal strain Candida albicans $(\mathrm{MICs}=96-205 \mu \mathrm{M})$. Ruta chalepensis has long been used in Iraqi traditional medicine to treat various diseases including microbial infections $[3,4]$. Antimicrobial assay-guided isolation of rutin (1) 
and its derivatives ( $\mathbf{2}$ and $\mathbf{3}$ ) as active components and subsequent assessment of their antimicrobial properties have provided some scientific evidence for the traditional use of $R$. chalepensis to treat infections.

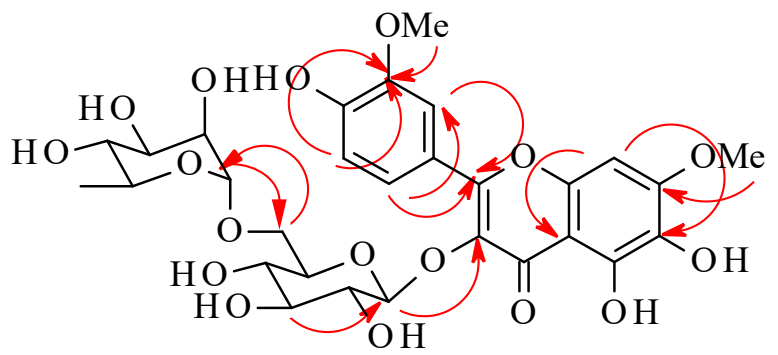

Figure 2. ${ }^{1} \mathrm{H}-{ }^{13} \mathrm{C}$ HMBC selected long-range key correlations of compound $\mathbf{3}$

Rutin (1) is one of the most common flavonol glycosides, especially found in the plants from the family Rutaceae, and has been extensively studied to establish its various bioactivities including antibacterial and antifungal properties [16, 21-23]. Therefore, the antimicrobial activities of rutin (1) and its analogues ( $\mathbf{2}$ and $\mathbf{3}$ ), including a new one (3), as observed in the present study, are in agreement with previous reports [16, 21-23]. All these compounds (1-3) were found to be bacteriostatic [24,25] as there was microbial regrowth, when under aseptic condition, $100 \mu \mathrm{L}$ of culture from the rows of MIC in the microtitre plates was transferred to an empty petri dish, $20 \mathrm{~mL}$ of nutrient agar was added, and incubated at $37^{\circ} \mathrm{C}$ for $24 \mathrm{~h}$.

\section{Acknowledgments}

Mass spectrometry data were acquired at the EPSRC UK National Mass Spectrometry Facility at Swansea University. Shaymaa Al-Majmaie thanks the Iraqi Ministry of Higher Education and Scientific Research, and Department of Biosciences, College of Science, University of Diyala, Iraq, for a PhD Scholarship to carry out this study.

\section{Supporting Information}

Supporting Information accompanies this paper on http://www.acgpubs.org/RNP

\section{ORCID}

Shaymaa Al-Majmaie:0000-0003-3860-8188

Lutfun Nahar: https:0000-0002-1157-2405

George P. Sharples:0000-0003-0492-0253

Khazal Wadi: https:0000-0003-1136-0485

Satyajit Dey Sarker:0000-0003-4038-0514

\section{References}

[1] I. Ouerghemmi, I. B. Rebey, F. Z. Rahali, S. Bourgou, L. Pistelli, R. Ksouri, B. Marzouk and M. S. Tounsi (2017). Antioxidant and antimicrobial phenolic compounds from extracts of cultivated and wildgrown Tunisian Ruta chalepensis, J. Food Drug Anal. 25, 350-359.

[2] A. Pollio, A. De Natale, E. Appetiti, G. Aliotta, and A. Touwaide (2008). Continuity and change in the Mediterranean medical tradition: Ruta spp. (Rutaceae) in Hippocratic medicine and present practices, $J$. Ethnopharmacol. 116, 469-482.

[3] K. Günaydin and S. Savci, S (2003). Phytochemical studies on Ruta chalepensis (LAM.) Lamarck, Nat. Prod. Res. 19, 203-210.

[4] M. S. Al-Said, M. T. Yahia, S. R. Ginnawi and A. M.Ageel (1990). Studies on Ruta chalepensis, an ancient medicinal herb still used in traditional medicine, J. Ethnopharmacol. 23, 305-312.

[5] L. Aguilar-Santamaria, and J. Tortoriello (1995). Anticonvulsant and sedative effects of crude extracts of Ternstroemia pringlei and Ruta chalepensis, Phytother. Res. 10, 531-533. 
[6] M. S. Ali-Shtayeh and S. I. Abu Ghdeib (1990). Antifungal activity of plant extracts against dermatophytes. Mycoses. 42, 665-672.

[7] M. E. Gonzalez-Trujano, D. Carrera, R. Ventura-Martinez, E. Cedillo-Portugal and A. Navarrete (2006). Neuropharmacological profile of an ethanol extract of Ruta chalepensis L. in mice, J. Ethnopharmacol. 106,129-135.

[8] L. Iauk, K. Mangano, A. Rapisarda, S. Ragusa, L. Maiolino, R. Musumeci, R. Costanzo, A. Serra, A. and A. Speciale (2004). Protection against murine endotoxemia by treatment with Ruta chalepensis L. a plant with anti-inflammatory properties, J. Ethnopharmacol. 90, 267-272.

[9] K. El Sayed, M. S. Al-Said, F. S. El-Feraly and S. A. Ross (2000). New quinoline alkaloids from Ruta chalepensis, J. Nat. Prod. 63, 995-997.

[10] A. Emam, M. Eweis and M. Elbadry (2010). A new furoquinoline alkaloid with antifungal activity from the leaves of Ruta chalepensis, Drug Dis. Therap. 4, 399-404.

[11] M. Hamdiken, S. Bouhalit and Z. Kechrid (2017). Effect of Ruta chalepensis on zinc, lipid profile and antioxidant levels in the blood and tissue of sterptozotocin-induced diabetes in rats fed zinc-deficient diets, Can. J. Diabetes DOI:10.1016/j.jcjd.2017.08.239.

[12] E. Ortu, G. Sanna, A. Scala, G. Pulina, P. Caboni and G. Battacone (2017). In vitro anthelmintic activity of active compounds of the fringed rue Ruta chalepensis against dairy ewe gastrointestinal nematodes, J. Helminthol. 91, 447-453.

[13] A.Khadri, I. Bouali, S. Belkhir, R. Mokded, S. Smiti, P. Fale, M. E/ M. Araujo and M. L. M. Serralheiro (2017). In vitro digestion, antioxidant and antiacetylcholinesterase activities of two species of Ruta: Ruta chalepensis and Ruta montana, Pharm. Biol. 55, 101-107.

[14] M. Kacem, G. Simon, R. Leschiera, L. Misery, A. El-Feki and N. Lebonvallet (2015). Antioxidant and anti-inflammatory effects of Ruta chalepensis L. extracts on LPS-stimulated RAW 264.7 cells, In Vitro Cell. Dev. Biol. Animal 51, 128-141.

[15] R. M. Sghaier, D. Khlifi, M. Hamdi, J. Boujila and D. Laouini (2013). Ruta chalepensis: a promising phytotherapeutic candidate against multiple forms of cancer, Eur. J. Cancer 49, S179.

[16] F. Fathiazad, A. Delazar and S. D. Sarker (2006). Extraction of flavonoids and quantification of rutin from waste tobacco leaves, Iranian J. Pharm. Res. 3, 222-227.

[17] J. Kagan and T. J. Mabry (1969). Isorhamnetin 3-O-rutinoside, the flavonoid pigment in Batis maritima, Phytochemistry 8, 325-326.

[18] T. Mabry, K. R. Markham and M. B. Thomas (1970). The Systematic Identification of Flavonoids, Springer-Verlag, Berlin Heidelberg, pp. 1-354.

[19] S. D. Sarker, Y. Kumarasamy and L. Nahar (2007). Microtitre plate-based antibacterial assay incorporating resazurin as an indicator of cell growth, and its application in the in vitro antibacterial screening of phytochemicals, Methods 42, 321-324.

[20] T. Wu, M. He, X. Zang, Y. Zhou, T. Qiu, S. Pan and X. Xu (2013). Structure-activity relationship study of flavonoids as inhibitors of E. coli by membrane interaction effect, Biochimica et Biophysica Acta, 1828, 2751-2756.

[21] M. M. Almutairi, W. A. Alanazi, M. A. Alshammari, M. R. Alotaibi, A. R. Alhoshani, S. S. Al-Rejaie, M. M. Hafez and O. A. Al-Shabanah (2017). Neuro-protective effect of rutin against cisplatin-induced neurotoxic rat model, BMC Complement. Alt. Med. 17, 472.

[22] D. D. Orhan, B. Özçcelik, B. Özgen and F. Ergun (2009). Antibacterial, antifungal, and antiviral activities of some flavonoids, Microbiol. Res. 165, 496-504.

[23] R. B. D. Q. Pimentel, C. A. D. Costa, P. M. Albuquerque and S. D. Junior (2013). Antimicrobial activity and rutin identification of honey produced by the stingless bee Melipona compressipes manaosensis and commercial honey, BMC Complement. Alt. Med. 13, 151.

[24] S. Bernatová, O. Samek, Z. Pilát, M. Šerý, J. Ježek, P. Jákl, M. Šiler, V. Krzyžánek, P. Zemánek, V. Holá, M. Dvořáčková and F. Růžička, F. (2013). Following the mechanisms of bacteriostatic versus bactericidal action using raman spectroscopy, Molecules 18, 13188-13199; doi:10.3390/molecules 181113188

[25] G. A. Pankey and L. D. Sabath (2004). Clinical relevance of bacteriostatic versus bactericidal mechanisms of action in the treatment of Gram-positive bacterial infections, Clin. Infect. Dis. 38, 864870 .

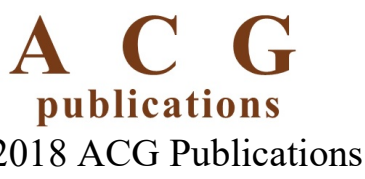

